\title{
Keyword Index to Volume 38, 2013
}

(Page numbers with $\mathrm{J}$ indicate keywords in the contents published in Japanese Journal of Pesticide Science.)

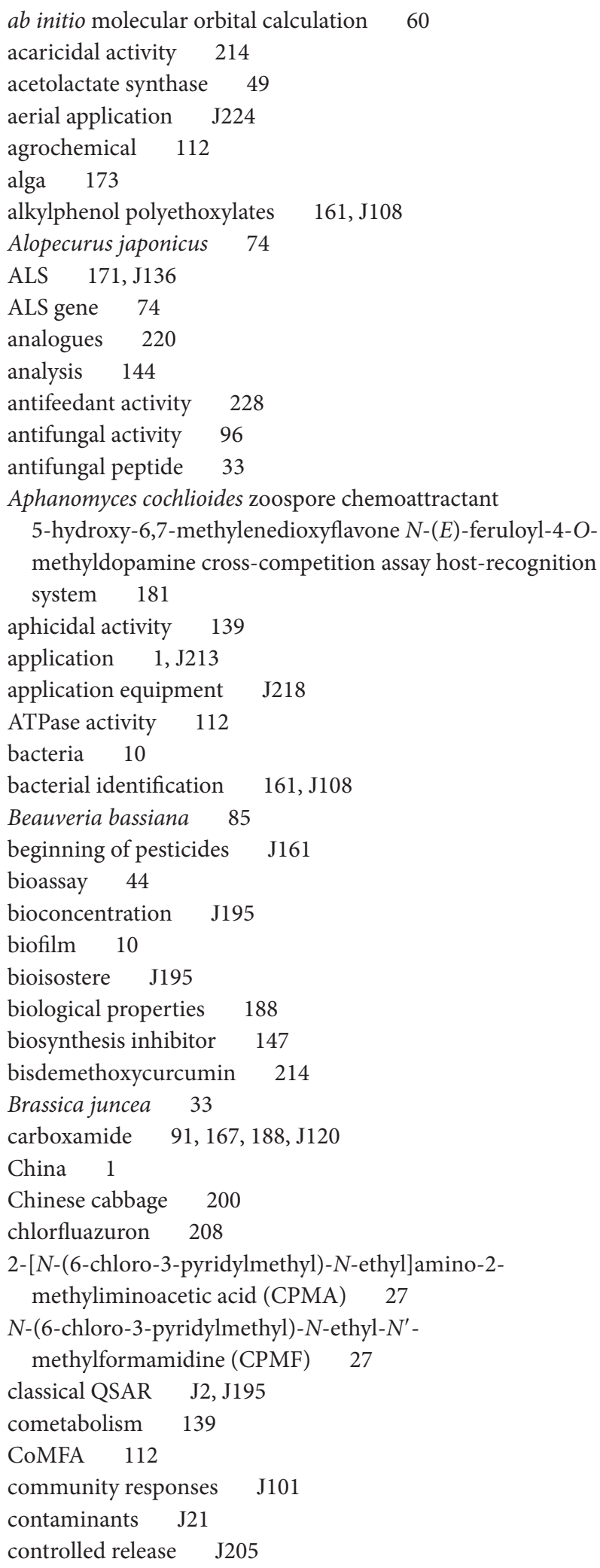

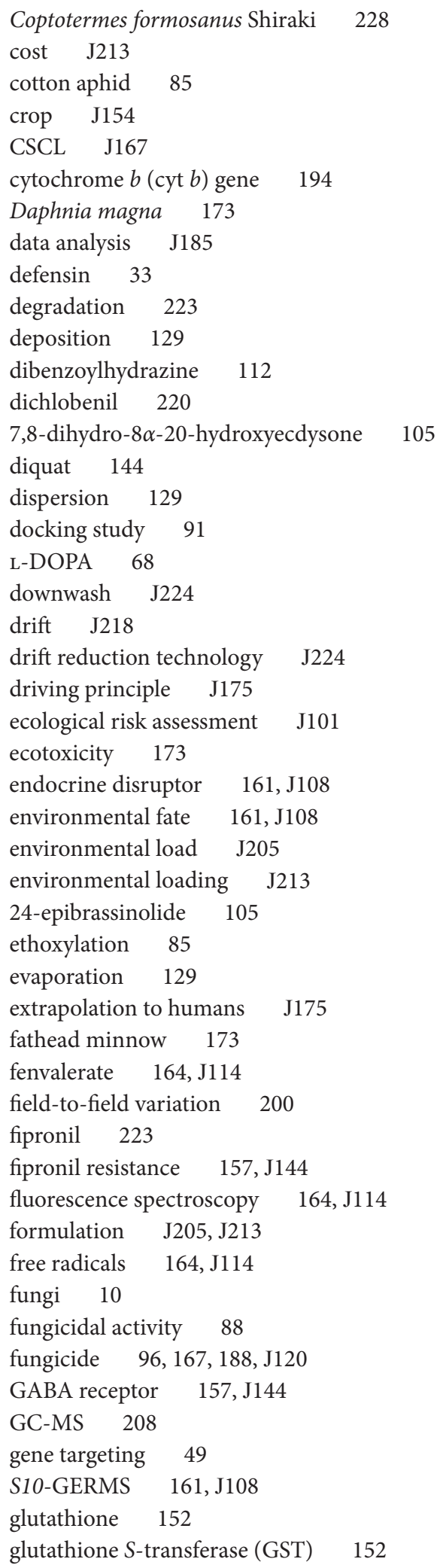




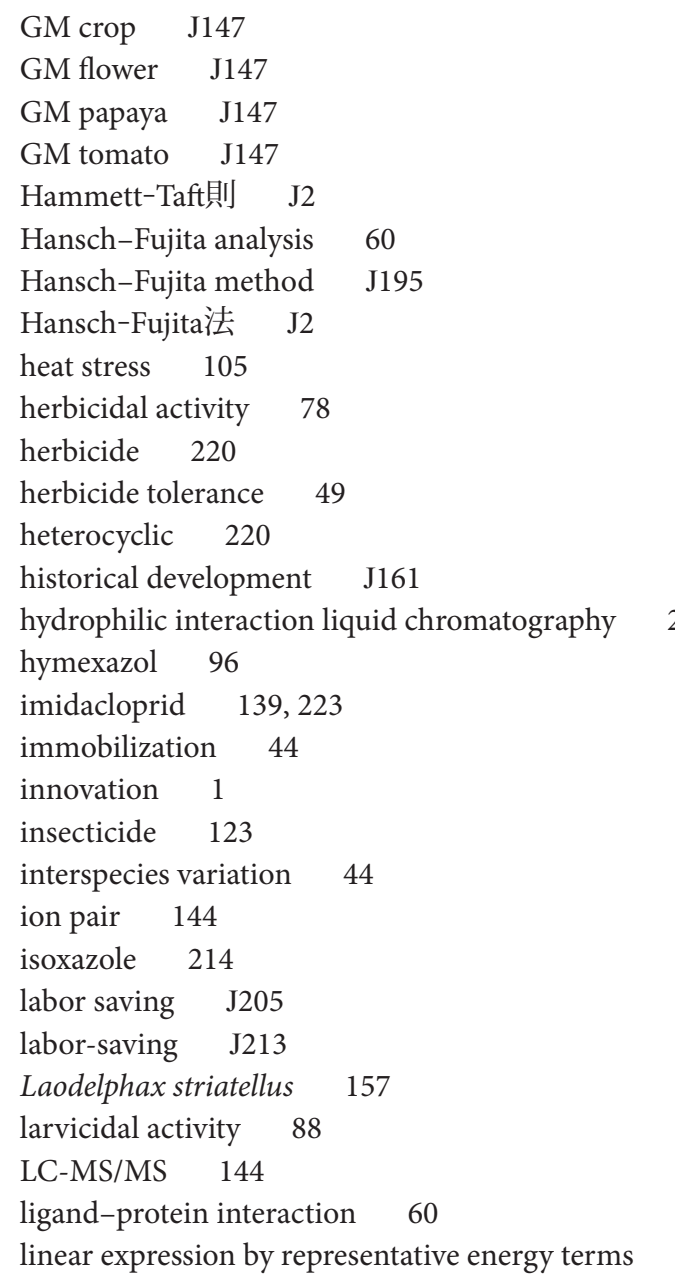

$$
\text { (LERE) } 60
$$

long-term monitoring $\quad \mathrm{J} 101$

Macrotermes gilvus 208

Magnaporthe oryzae 33

MALDI-TOF MS 161, J108

MBIs 194

mesocosm J101

mesosulfuron-methyl 74

metabolism 152

metabolite 173

meta-diamide 123

metofluthrin 173

microbial aerobic transformation 10

Microdochium nivale 96

mode of action J175

molecular design $\quad$ J185

Molecular phylogeny 194

MTF-753 167, J120

Mucuna pruriens 68

mutation 74

N group 39

neonicotinoid 1

new plant breeding techniques J147

nitenpyram 27 nozzle J218

Octanol-水系分配 J2

Odonata J101

one-shot herbicide $171, \mathrm{~J} 136$

Oryza sativa 105

oxime ether 88

P450 147

paddy water 223

paraquat 144

PCR-RFLP 157

penthiopyrad 91, 167, 188, J120

pesticide $44,129, \mathrm{~J} 101$

pesticide analysis 208

pesticide delivery system J205

pesticide guideline studies $\quad \mathrm{J} 175$

pesticide industry in Japan J161

pesticide residue $169,200, \mathrm{~J} 21, \mathrm{~J} 130$

P-glycoprotein 112

$\mathrm{pH} \quad 223$

phenylboronic acid $\quad 228$

phosphinate 78

photolysis 164, J114

plant vaccine $\mathrm{J} 147$

point mutation 49

pollen 105

polyphenol oxidase 68

POPRC J167

POPs J167

positional isomer 91

precocene 228

pretreatment 139

production 1

proteomics J154

pyrazole 214

pyrimisulfan 171, J136

pyroxasulfone 152

QoIs 194

QSAR J185

QSAR parameter J195

quantitative structure-activity relationship (QSAR) 60

quinone 68

radical-trapping $164, \mathrm{~J} 114$

raw agricultural commodity $\quad 169, \mathrm{~J} 130$

RDL GABA receptor 123

reactive oxygen species $\quad 68$

resistance 74

Rhizoctonia solani 96

risk analysis $\mathrm{J} 21$

risk assessment J147

safety J205

SAICM J167

sampling size $169, \mathrm{~J} 130$

selectivity 152

semisynthesis 214 


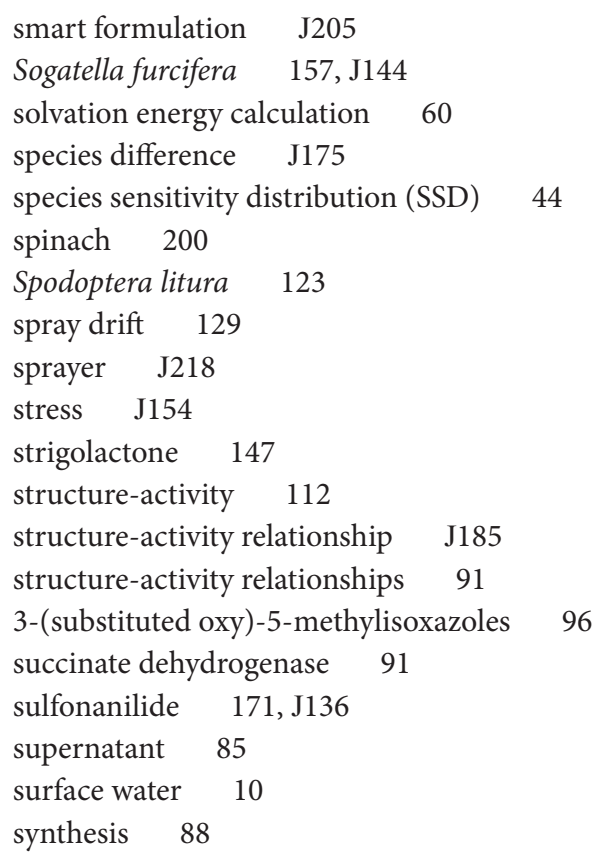

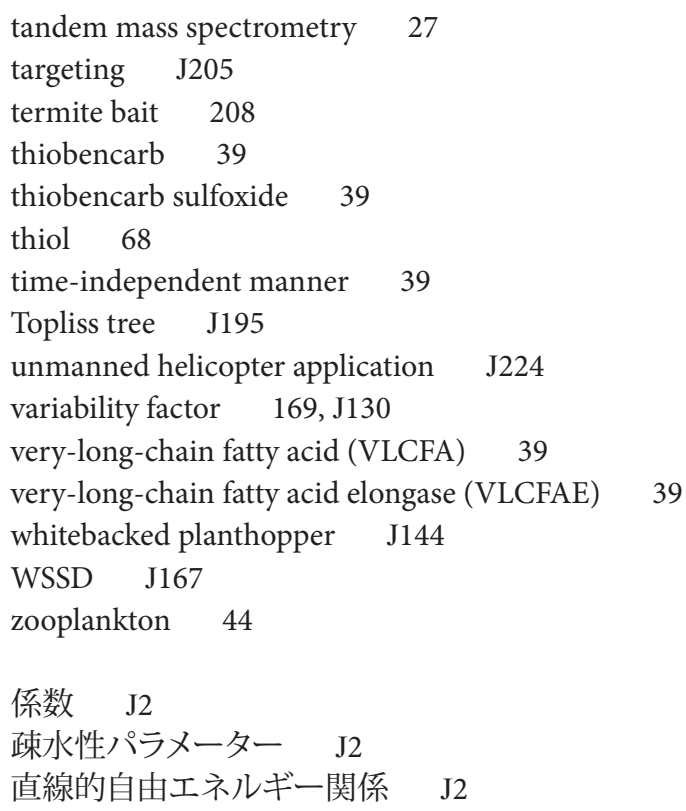

